\title{
Pengalaman Hidup Orang Terinfeksi Filariasis
}

\author{
Lilis Lismayanti ${ }^{1}$, Kusman Ibrahim $^{2}$, Lia Meilianingsih $^{3}$ \\ ${ }^{1}$ Stikes Tasikmalaya, ${ }^{2}$ Fakultas Keperawatan Universitas Padjadjaran, ${ }^{3}$ Politeknik Kemenkes Bandung \\ ${ }^{3}$ Poltekkes Kemenkes Bandung \\ Email: lilismayanti@gmail.com
}

\begin{abstract}
Abstrak
Filariasis merupakan penyakit yang kurang diperhatikan, karena penderita cenderung mengalami stigma negatif. Penelitian ini bertujuan mengeksplorasi pengalaman hidup orang terinfeksi filariasis. Penelitian menggunakan metode deskriptif kualitatif dengan pendekatan fenomenologi. Tujuh partisipan berpartisipasi dalam penelitian ini. Analisis data menggunakan pendekatan Collaizi. Hasil penelitian mendapatkan lima tema dan 16 subtema. Pertama, pengalaman pertama kali terinfeksi filariasis dengan subtema kaget, bingung, dan perasaan tidak menentu. Kedua, pengalaman orang terinfeksi filariasis selama menjalani gejala klinisnya dengan subtema demam, nyeri, bengkak, keterbatasan aktivitas, dan kelelahan. Ketiga, gangguan emosi dan psikologis dengan subtema malu, jengkel, dan pasrah. Keempat, adanya beban sosial ekonomi dengan subtema menarik diri dari interaksi sosial dan kesulitan ekonomi. Kelima, pengalaman orang terinfeksi filariasis dalam mengakses pelayanan kesehatan dengan subtema penyakit yang tidak kunjung sembuh setelah beberapa kali berobat ke pelayanan kesehatan, mencari alternatif pengobatan, pelayanan kesehatan yang kurang memuaskan dan harapan pelayanan kesehatan yang lebih baik. Hasil penelitian ini dapat dijadikan acuan untuk meningkatkan pelayanan keperawatan komunitas, baik pada kelompok yang sakit, yang beresiko dan yang sehat, dengan upaya promotif, preventif, kuratif dan rehabilitatif.
\end{abstract}

Kata kunci: Fenomenologi, filariasis, pengalaman hidup

\section{The Live Experience of People with Filariasis}

\begin{abstract}
Filariasis is a disease that is less noted, because people with filariasis tend to experience negative stigma. This study aims to explore the lived experience of people infected with filariasis. This study is descriptive qualitative with phenomenological approach. Seven (7) participants involved in this study. Data was analized using Collaizi's approach to analysis. The results of this study found 5 themes with 16 subthemes. First, the experience at first infected with filariasis with subthemes: shock, confusion, and feeling uncertain. Second, filariasis infected people experience during their clinical symptoms with subtheme: Fever, pain, swelling, lack of activity, and fatigue. Third, filariasis infected people experience of emotional and psychological disturbance with subthemes: Shame, irritated, and surrender. Fourth, Socioeconomic burden with subthemes: withdraw from social interaction and economic hardship. Fifth, filariasis infected people experience in accessing health services with subthemes: Never recovered after several times getting treatment by health professional, seeking alternative treatment, unsatisfactory with health services and expectation of better health care. The results of this study can be used as a reference to improve community nursing services, either at hospital group, risk and healthy people, with promotive, preventive, curative and rehabilitative.
\end{abstract}

Key words: Filariasis, lived experience, phenomenology 
Lilis Lismayanti: Pengalaman Hidup Orang Terinfeksi Filariasis

\section{Pendahuluan}

Filariasis atau yang lebih dikenal dengan penyakit kaki gajah adalah penyakit yang disebabkan oleh infeksi parasit nematoda. Penyakit yang menjadi masalah kesehatan masyarakat ini telah tersebar di seluruh dunia, terutama di negara tropis dan subtropis. Sudomtung pada jenis spesiesnya.

Penyakit filariasis yang telah kronik, seringkali luput dari perhatian tenaga kerja kesehatan. Hal demikian terjadi karena penderita tidak berupaya untuk mencari bantuan pelayanan kesehatan, tidak mau keluar rumah, malu untuk bertemu orang lain, takut dicemooh, dikucilkan, serta adanya stigma dari masyarakat sebagai penyakit yang menjijikkan. Selain hal tersebut, penyakit filariasis juga diyakini berhubungan dengan kekuatan gaib, sihir, atau supranatural.

Indonesia merupakan negara endemis terbesar di Asia Tenggara untuk tiga spesies Filaria penyebab filariasis limfatik (Krentel, dkk., 2006). Saat ini sekitar 495 negara diperkirakan mempunyai population at risk 1,3 milyar, 180 juta orang tinggal di daerah endemi filariasis, lebih dari 120 juta orang diantaranya sudah terinfeksi, 43 juta orang sudah menunjukkan gejala klinis berupa pembengkakkan anggota tubuh di kaki atau lengan (lymphoedema) atau anggota tubuh lainnya (World Health Organization [WHO], 2011 \& Hotez, dkk., 2007).

Kasus filariasis di Indonesia yang dilaporkan Kementrian Kesehatan Republik Indonesia sampai tahun 2009 sebanyak 11.914 yang tersebar di 401 kabupaten atau kota. Jumlah tersebut merupakan jumlah kumulatif dari penderita lama yang baru ditemukan maupun penderita baru. Jumlah penderita filariasis di Jawa Barat mengalami peningkatan yang signifikan dalam kurun waktu tiga tahun terakhir. Pada tahun 2006, penderita filariasis ditemukan sebanyak 252 kasus, sedangkan tahun 2007 jumlah temuan meningkat 13 kasus dari tahun sebelumnya. Puncaknya pada tahun 2008 temuan jumlah penderita filariasis melonjak tajam hingga 404 kasus. Laporan Subdinas Penyehatan Lingkungan Dinas Kesehatan Provinsi Jawa Barat tahun 2008, terdapat sembilan daerah endemis filariasis. Jumlah penderita terbesar ditemukan di kabupaten Bekasi sebanyak
69 kasus, Kota Bekasi sebanyak 39 kasus, kabupaten Tasikmalaya sebanyak 37 kasus, Bogor sebanyak 35 kasus, dan Kuningan sebanyak 25 kasus (Kementrian Kesehatan Republik Indonesia, 2010).

Kasus filariasis tersebar di 20 wilayah kerja puskesmas di Tasikmalaya. Jumlah kasus terbanyak terdapat di Puskesmas Tamansari. Penderita filariasis di wilayah tersebut terdapat 19 kasus filariasis kronik dan 12 kasus diantaranya mengalami kecacatan pada tungkai bawah sebelah kiri, enam kasus mengalami kecacatan pada tungkai bawah sebelah kanan, dan satu orang mengalami pembengkakan di seluruh tubuhnya. Kasus penderita filariasis yang dilaporkan di Kota Tasikmalaya tersebut hanya kasus kronik, sedangkan kasus positif yang belum menunjukkan gejala spesifik belum termasuk didalamnya (Dinas Kesehatan Provinsi Jabar, 2005).

Penyakit filariasis dapat berupa filariasis tanpa gejala dan dengan gejala peradangan. Filariasis tanpa gejala umumnya terjadi di daerah endemik. Pada pemeriksaan fisik hanya ditemukan pembesaran kelenjar limfe terutama di daerah inguinal. Pada pemeriksaan darah ditemukan mikrofilaria dalam jumlah besar dan eosinofilia. Filariasis dengan peradangan dapat berupa demam, menggigil, sakit kepala, muntah dan lemah yang dapat berlangsung beberapa hari sampai beberapa minggu. Pada laki-laki umumnya terdapat funikulitis disertai penebalan dan rasa nyeri, epididimitis, orkitis, dan pembengkakan skrotum. Pada wanita dapat terjadi elephantiasis pada vagina dan payudara.

Kecacatan fisik yang dialami oleh penderita filariasis memberikan dampak pada mobilitas fisik, psikologis, sosial, dan ekonomi. Kecacatan fisik sangat menghambat aktivitas sehari-hari penderita filariasis, hal demikian sesuai dengan hasil penelitian yang dilakukan oleh Omudu, Agbo, Okafor, dan Chukwuemenam (2011) dan Kanda (2004), bahwa pada episode akut filariasis membatasi kemampuan perempuan untuk melakukan pekerjaan rumah tangga seperti memasak, menjaga, atau merawat anak-anak. Hasil penelitian yang dilakukan Kumari, Harichandrakumar, Das, dan Krisnamoorthy (2005) dalam studi kasusnya 
Lilis Lismayanti: Pengalaman Hidup Orang Terinfeksi Filariasis

menyatakan bahwa dalam keadaan filariasis akut, mobilitas fisik terkena dampak yang berat sehingga penderita sangat tergantung pada keluarga untuk perawatan dirinya.

Kecacatan yang irreversible merupakan pemicu utama bagi penderita filariasis terjadinya gangguan psikologis berupa perasaan malu, kecemasan, depresi, bahkan ada upaya untuk bunuh diri. Studi kasus yang dilakukan Bose (2011), penderita merasa tertekan dengan kondisi fisiknya karena harus diamputasi, dan sebelum bertemu dengan peneliti penderita pernah mencoba untuk bunuh diri. Dampak psikologis ini bertambah berat sesuai dengan tingkat kecacatan fisiknya. Laporan studi kasus yang dilakukan Kumari, Harichandrakumar, Das, dan Krishna Moorthy (2005) menemukan bahwa ada partisipan yang mengalami menggigil di kendaraan umum dan jatuh dimana saja saat terjadi serangan akut. Kejadian tersebut berulang, sehingga mengakibatkan kecemasan karena selalu ada kekhawatiran bahwa serangan akan terjadi lagi di depan banyak orang. Sebagian besar penderita mengatakan bahkan berpikir untuk mengakhiri hidup mereka daripada menanggung penderitaannya.

Kecacatan akibat filariasis tidak hanya berdampak terhadap psikologisnya, tetetapi juga akan berdampak terhadap keadaan sosial dan ekonomi penderita. Kecacatan fisik akan menimbulkan perasaan malu, takut diketahui orang lain, sehingga penderita menarik diri dari lingkungannya; kemudian kehilangan pekerjaan, yang selanjutnya berdampak terhadap ekonominya. Hal ini sejalan dengan hasil penelitian yang dilakukan oleh Wijesinghe, Wickremasinghe, Ekanayake, dan Parera (2007), penderita dilaporkan mengalami masalah berinteraksi dengan masyarakat dan keluarga, dan mereka merasa ditolak oleh masyarakat.

Dampak ekonomi bukan hanya disebabkan karena kehilangan pekerjaan, tetetapi juga karena bertambahnya beban ekonomi untuk perawatan. Laporan studi kasus yang dilakukan Kumari, dkk. (2005), penderita setiap episode akut kehilangan pekerjaan dan pendapatan, dan harus memenuhi pengeluaran untuk pengobatan, sedangkan hasil penghitungan Gani yang dikutip dari (Sudomo, 2008) bahwa biaya perawatan penderita filariasis sebesar $17,8 \%$ dari biaya total rumah tangga atau sekitar $32,2 \%$ dari biaya yang diperlukan untuk makan satu rumah tangga penderita filariasis .

Penelitian yang dilakukan Wynd, Melrose, Durrheim, Caron, \& Gaypong (2007) penderita limfatik filariasis kronik mengalami disfungsi seksual dan menghadapi stigma sosial sebagai akibat dari kecacatan mereka. Berdasarkan laporan hasil studi kasus Bose (2011) menemukan penderita sangat tertekan tentang kondisi adanya filariasis dan bahkan pernah ada upaya bunuh diri. Sejalan dengan penelitian WHO dalam (Kanda, 2004) terkait dengan aspek sosial, beban psikologis juga memengaruhi kehidupan pasien, biasanya orang depresi, sikap pasif, putus asa, dan fatalisme, dalam beberapa kasus bahkan mengarah pada upaya bunuh diri.

Penelitian Kanda (2004) didapatkan dari 316 responsden hanya dua orang yang mampu mengenali penyakitnya. Hampir setengah dari responsden mengandalkan pengobatan tradisional, hanya 30,1\% yang datang ke sarana kesehatan atau tenaga kesehatan. Tindakan yang dilakukan oleh responsden adalah menjaga kebersihan, rendam kaki dengan sabun, obat herbal, memakai kaos stocking, tetetapi ada juga yang melakukan tindakan yang bertentangan seperti mencuci kaki dan merendam dengan air dingin atau air seni, bukan menghindari air dingin atau mencuci kaki dengan air hangat, 90\% melaporkan bahwa mereka setidaknya percaya dengan kemampuan mereka untuk merawat kaki mereka. Lebih dari setengah responsden mengalami ketidaknyamanan atau nyeri dan lebih dari sepertiga responsden mengalami depresi. Rata-rata hari tidak sehat dalam sebulan adalah tujuh hari, tidak ada satupun dari reponden yang merasa sakit lebih dari seminggu. Faktor kecemasan lebih signifikan daripada faktor yang lain.

Dampak kompleksitas yang diakibatkan oleh penyakit filariasis sehingga sangat memungkinkan terjadinya perbedaan persepsi orang terhadap pengalaman selama menghadapi penyakitnya, dengan kata lain bahwa seseorang yang mempunyai pengalaman penyakit sama tidak menutup kemungkinan akan menimbulkan persepsi yang berbeda-beda. Penelitian kuantitatif tentang filariasis di Indonesia sudah 
Lilis Lismayanti: Pengalaman Hidup Orang Terinfeksi Filariasis

banyak dilakukan, sedangkan penelitian kualitatif masih jarang dilakukan apalagi yang berhubungan dengan pengalaman hidup orang terinfeksi filariasis, sehingga masih sedikit diketahui tentang pengalaman hidup orang terinfeksi filariasis di Indonesia khususnya di Tasikmalaya.

Penelitian ini dilakukan untuk mengeksplorasi lebih dalam mengenai pengalaman hidup orang yang pernah mengalami infeksi filariasis dalam menjalani kehidupan seharihari dengan penyakitnya. Hasil penelitian ini akan memberikan pemahaman yang mendalam kepada perawat tentang kehidupan orang terinfeksi filariasis, sehingga dapat dijadikan acuan dalam memberikan asuhan keperawatan secara holistik.

\section{Metode Penelitian}

Rancangan penelitian menggunakan penelitian kualitatif deskriptif dengan pendekatan fenomenologi. Penelitian ini dilakukan di Kota Tasikmalaya. Sampel menggunakan purposive sampling jumlah partisipan tujuh orang dengan pertimbangan telah saturasi. Kriteria partisipan adalah orang terinfeksi filariasis yang telah melewati stadium II, tinggal di Kota Tasikmalaya, telah mendapatkan pelayanan kesehatan khususnya puskesmas setempat, mampu menceritakan pengalamannya dan bersedia menjadi partisipan. Peneliti merupakan instrumen utama dalam penelitian ini dan menggunakan alat bantu berupa panduan wawancara, catatan lapangan, perekam suara dan kamera. Data dikumpulkan dengan wawancara mendalam. Analisis data menggunakan pendekatan Collaizi.

\section{Hasil Penelitian}

Hasil penelitian mendapatkan lima tema dan 16 subtema. Pertama, pengalaman pertama kali terinfeksi filariasis dengan subtema kaget, bingung, dan perasaan tidak menentu. Kedua, pengalaman orang terinfeksi filariasis selama menjalani gejala klinisnya dengan subtema demam, nyeri, bengkak, keterbatasan aktivitas, dan kelelahan. Ketiga, gangguan emosi dan psikologis dengan subtema malu, jengkel, dan pasrah. Keempat, adanya beban sosial ekonomi dengan subtema menarik diri dari interaksi sosial dan kesulitan ekonomi. Kelima, pengalaman orang yang terinfeksi filariasis dalam mengakses pelayanan kesehatan dengan subtema penyakit yang tidak kunjung sembuh setelah beberapa kali berobat ke pelayanan kesehatan, mencari alternatif pengobatan, pelayanan kesehatan yang kurang memuaskan dan harapan pelayanan kesehatan yang lebih baik.

Hasil penelitian yang berkenaan dengan pengalaman orang terinfeksi filariasis ketika pertama kali didiagnosis filariasis didapatkan tiga subtema, yaitu kaget, bingung, dan perasaan tidak menentu. Berikut ini ungkapan dari partisipan dari setiap subtema :

a. Kaget

Tiga dari tujuh partisipan merasa kaget ketika pertama kali didiagnosis filariasis. Partisipan yang didiagnosis filariasis mengungkapkan hal tersebut tidak lama setelah munculnya gejala bengkak, berikut ini sebagian dari ungkapan partisipan:

“Ya pasti takut, kaget...,"(Partisipan 2)

"Tentunya juga kaget, seperti kena petir...," (tampak menutup matanya dan menggelengkan kepala)(Partisipan 7)

"Kaget...kan ingin sembuh." (Partisipan 4)

\section{b. Bingung}

Empat dari tujuh partisipan merasa bingung ketika pertama kali didiagnosis filariasis, perasaan bingung terjadi karena mengetahui bahwa penyakitnya tidak dapat disembuhkan dan harus menjalani penyakitnya dalam waktu yang tidak pasti. Berikut ini ungkapan sebagian dari partisipan:

"Ya pasti takut,....,bingung...," (partisipan mengerutkan dahi). (Partisipan 2)

“...Bingung, sedih, sudahlah campur aduk, kan ingin sembuh..."(partisipan tertunduk). (Partisipan 4)

Bingung diungkapkan partisipan 1 dan partisipan 3 saat menginjak dewasa ketika mulai mengerti tentang kaki gajah. Berikut salah satu ungkapan dari partisipan:

"Saat itu tidak apa-apa, mungkin saat itu saya masih kecil jadi belum tahu apa maksudnya,... setelah remaja mengerti, baru 
Lilis Lismayanti: Pengalaman Hidup Orang Terinfeksi Filariasis

merasa bingung”. (Partisipan 1)

c. Perasaan tidak menentu

Tiga dari tujuh partisipan ada yang merasakan perasaan tidak menentu ketika pertama kali didiagnosis filariasis, perasaan tidak menentu ini diakibatkan karena ketidakpastian dengan penyakitnya, berikut ungkapan salah satu partisipan:

"Perasaan tidak menentu, pikiran tidak pasti". (tampak partisipan meremas-remas tangannya). (Partisipan 4)

Pengalaman orang terinfeksi Filariasis selama menjalani gejala fisiknya ditemukan lima tema, yaitu demam, nyeri, bengkak, keterbatasan aktivitas, dan kecapean.

\section{a. Demam}

Semua partisipan pernah mengalami demam selama menjalani penyakitnya, berikut ini sebagian dari ungkapan partisipan:

"...seperti ini demam seperti bisul yang belum pecah,". (Partisipan 1)

"Kalau sedang kambuh segala macam, demam dulu”. (Partisipan 3)

\section{b. Nyeri}

Seluruh partisipan mengalami gejala fisik berupa nyeri, keluhan nyeri diungkapkan oleh partisipan dengan bahasa yang berbeda -beda sesuai dengan tingkat dan karekteristik nyeri yang dirasakannya. Berikut ini ungkapan dari sebagian partisipan tentang nyeri:

"Nah ini sebelah sini, nyeri seperti diremasremas," (partisipan menunjukkan daerah yang nyeri sambil meringis) (Partisipan 1)

“...awalnya nyeri seperti ditusuk, ini sebelah kanan,.." (partisipan menunjukkan kakinya yang dirasakan nyeri) (Partisipan 2)

\section{c. Bengkak}

Gejala bengkak dialami oleh semua partisipan, ada partisipan yang merasakan bengkak dengan disertai benjolan, bernanah, mengeras, dan ada juga hanya gejala bengkak yang muncul. Berikut ini ungkapan sebagian partisipan:

"...jadi ininya bengkak sebelah, kemudian menonjol, dan pecah sebelah sininya..." (partisipan menunjukkan kakinya yang bengkak dan ada luka yang masih basah).
(Partisipan 1)

d. Keterbatasan aktivitas

Seluruh partisipan mengalami keterbatasan aktivitas sebagai dampak dari gejala fisiknya. Keterbatasan aktivitas ini dikarenakan kakinya yang bengkak, juga karena nyeri. Berikut adalah ungkapan sebagian partisipan: "Jangankan kerja yang berat, kalau sholatpun kadang-kadang terbatas, duduk juga tidak dapat, nah ini kan kaku, saking kerasnya.". (Partisipan 2)

\section{e. Kecapean}

Empat dari tujuh partisipan mengatakan bahwa kambuhnya penyakit terjadi apabila telah kecapean. Berikut ini adalah ungkapan sebagian partisipan:

"Agak cape kerja di rumah juga sama, suka kambuh. Dulu waktu masih ini masih suka digendong, malamnya suka kambuh." (Partispan 6)

Hasil penelitian berkenaan dengan pengalaman penderita filariasis terkait aspek emosi dan psikologis, didapatkan tiga tema yaitu malu, jengkel, dan pasrah.

\section{a. Malu}

Dua dari tujuh partisipan hanya mengatakan malu karena kakinya yang bengkak dan berbeda dari yang lainnya, berikut ungkapan partisipan :

"Tidak gimana-gimana, ah malu saja," (Partisipan 1)

"Cuma malu saja sayanya.". (Partisipan 7)

Perasaan malu akan berkurang karena partisipan sudah mampu beradaptasi dengan kondisi yang berbeda dengan orang lain, berikut ungkapan partisipan:

"...soalnya malu...ah sekarang mah PD (percaya diri) aja". (Partisipan 5)

Tiga dari tujuh partisipan merasa malu, perasaan malu akan semakin meningkat dengan semakin besarnya ukuran bengkak, berikut ini ungkapan partisipan:

"Entah kalau seperti kaki gajah mah, kayanya malu membukanya juga. Ini kan masih membentuk". (Partisipan 2) 
Lilis Lismayanti: Pengalaman Hidup Orang Terinfeksi Filariasis

\section{b. Jengkel}

Dua dari tujuh partisipan merasa jengkel, hal ini terjadi karena merasa malu dengan kecacatannya dan karena penyakitnya yang tidak kunjung sembuh, berikut ungkapan partisipan:

"Ah saya sudah nasib saya, malu pasti malu dong neng. Diantara keluarga, hanya saya yang punya cacat begini..sampai suka jengkel, nangis sudah cape...”. (Partisipan 3)

\section{c. Pasrah}

Keadaan fisik yang diakibatkan oleh penyakit filariasis membuat partisipan menjadi malu dan jengkel. Pada keadaan penyakit yang tidak kunjung sembuh, akhirnya partisipan pasrah. Hal ini dikemukan oleh enam dari tujuh partisipan. Berikut sebagian ungkapan dari partisipan:

“...tetapi saya tidak menjadi kebencian, berserah diri saja kepada Alloh sudah takdir harus begini......sudah gimana-gimana, ah saya sudahlah pasrah saja menghadapi kehidupan seperti ini...". (Partisipan 3)

"Kalau sekarang mau bagaimana juga silahkan, sudah pasrah. Sudah terlalu lama”. (Partisipan 4)

Hasil penelitian berkenaan dengan pengalaman penderita filariasis selama menjalani beban sosial ekonomi didapatkan dua tema yaitu menarik diri dari interaksi sosial, kesulitan ekonomi. Lebih jelasnya peneliti dideskripsikan sebagai berikut:

a. Menarik diri dari interaksi sosial

Respons masyarakat yang kurang baik dan perasaan malu karena keadaan fisik yang berbeda dengan yang lain membuat partisipan menarik diri dari interaksi sosial. Berikut sebagian ungkapan partisipan:

"Dulu tuh saya suka pengajian, tiap minggu tidak kelewat... nah waktu saya kambuh, ibu-ibu pengajian nengok...saya mendengar dengan telinga sendiri ada yang bilang begini, jangan ke dalam ah, jijik....lagian menular... sampai sekarang mulai dari sakit tidak pernah ngaji lagi, habis malu, kan bilangnya begitu". (Partisipan 7)

b. Kesulitan ekonomi
Kesulitan ekonomi dirasakan oleh lima dari tujuh partisipan, berikut ungkapan salah satu partisipan:

"Yang membuat saya sedih waktu saya mencari pekerjaan, tidak ada yang mau menerima, karena fisik saya tidak normal, saya sudah melamar kesana kemari, sudahlah akhirnya saya putus asa. Ya...akhirnya bekerja seperti ini, jadi buruh lepas... ah, yang pasti mah keuangannya yang tidak memungkinkan...". (Partisipan 5)

Hasil Penelitian yang berkenaan dengan pengalaman penderita filariasis dalam mengakses pelayanan kesehatan didapatka tiga tema, yaitu bosan dengan penyakit yang tidak kunjung sembuh setelah beberapa kali ke pelayanan kesehatan akhirnya mencari alternatif pengobatan tradisional dan dukun, pelayanan yang kurang memuaskan, dan harapan pelayanan yang lebih baik. Lebih jelasnya peneliti paparkan sebagai berikut :

a. Bosan dengan penyakit yang tidak kunjung sembuh setelah beberapa kali ke pelayanan kesehatan akhirnya mencari alternatif pengobatan tradisional dan dukun

Enam dari tujuh partisipan melakukan pengobatan ke pelayanan kesehatan, karena tidak kunjung sembuh partisipan datang ke dukun. Berikut ungkapan salah satu partisipan :

"Pokoknya mulai dari obat warung, puskesmas, rumah sakit sudah dikunjungi, yang belum mah dokter spesialis, waktu itu mah belum ada dokter spesialis kulit... ke kampung atau dukun, sama pengobatan tradisional juga pernah." (Partisipan 5)

b. Pelayanan kesehatan yang kurang memuaskan.

Empat dari tujuh partisipan merasakan pelayanan kesehatan yang diberikan kurang memuaskan, berikut ungkapan partisipan:

"Ah acuh tak acuh saja, kurang memperhatikan”. (Partisipan 3)

"Biasa-biasa. Kurang memuaskan.Maklum ke yang tidak ada biaya, ditambah keadaannya begini. Kurang memuaskan... dalam pemeriksaan, cuma diperiksa saja, dilihat, dikasih rujukan saja ke Bandung. Tidak 
Lilis Lismayanti: Pengalaman Hidup Orang Terinfeksi Filariasis

dijelaskan harus diperiksa gimana-gimananya,... diperiksa langsung dikasih rujukan, jadi tidak dikasih obat. Di puskesmas begitu, di rumah sakit juga sama.". (Partispan 4)

c. Harapan pelayanan kesehatan yang lebih baik

Seluruh partisipan mempunyai harapan terhadap pelayanan kesehatan yang lebih baik, berikut ini ungkapan sebagian partisipan:

"Ya, pelayanannya harus ditingkatkan saja," (Partisipan 4)

"Lebih baik saja, terus kalau berobat tuh dijelaskan harus bagaimana-bagaimananya, supaya tidak bingung di rumahnya." (Partisipan 6)

\section{Pembahasan}

Hasil penelitian tentang pengalaman orang terinfeksi filariasis ketika pertama kali didiagnosis menderita filariasis didapatkan bahwa terdapat respons psikologis berupa kaget, bingung dan perasaan tidak menentu. Kaget merupakan respons yang muncul dan dirasakan oleh partisipan yang didiagnosis tidak lama dari mulai munculnya bengkak. Perasaan kaget merupakan respons psikologis terhadap ketidaksiapan dalam menghadapi sesuatu atau tidak menerima terhadap kenyataan yang terjadi.

Perasaan bingung dikarenakan adanya pemahaman yang terbatas dari partisipan tentang penyakit filariasis. Pemahaman partisipan tentang dampak yang diakibatkan oleh penyakit filariasis seperti tidak dapat disembuhkan, menular, adanya respons negatif dari masyarakat, maka akan meningkatkan perasaan bingung. Perasaan tidak menentu merupakan manifestasi dari ketidakpastian masa depan yang berhubungan dengan penyakitnya. Secara eksplisit ditemukan juga ungkapan cemas dari partisipan. Fenomena ini sesuai dengan hasil penelitian Kumari, dkk. (2005) dalam studi kasusnya menyatakan keadaan kecacatan yang kronik dan ketidakpastian proses penyembuhan membuat pikiran terganggu, mereka mengalami kecemasan atau depresi, bingung, 'linglung', dan tidak mampu berkonsentrasi yang pada akhirnya menyebabkan kehilangan minat.
Hasil penelitian pengalaman orang terinfeksi filariasis selama menjalani gejala klinis didapatkan lima subtema yaitu demam, nyeri, bengkak, keterbatasan aktivitas, dan kelelahan.

Demam, nyeri, dan bengkak merupakan manifestasi peradangan yang terjadi dikarenakan invasi parasit yang memasuki sirkulasi darah. Antigen parasit cacing dewasa dapat mengaktifkan sel $\mathrm{T}$, sehingga sel $\mathrm{T}$ dapat melepaskan sitokinin yang selanjutnya menstimuli sumsum tulang sehingga terjadi eosinofilia yang dapat meningkatkan mediator proinflamatori. Sitokinin juga akan merangsang meningkatkan produksi Immunoglobulin E (Ig E). Ig E yang terbentuk berikatan dengan parasit dan melepaskan mediator inflamasi sehingga timbul demam dan nyeri.

Invasi parasit yang memasuki sirkulasi, lalu menuju pembuluh limfa dan nodus limfa. Kerusakan pada pembuluh limfa dapat disebabkan oleh cacing dewasa ataupun oleh respons imun terhadap cacing dewasa yang hidup didalamnya, kemudian menginduksi terjadinya proliferasi sel endotel dan dilatasi limfatik. Respons imun terhadap cacing dewasa dapat menyebabkan granuloma inflamatorik. Kedua respons ini menyebabkan terjadinya obstruksi limfatik dan pada akhirnya terjadilah bengkak atau kaki gajah.

Gejala fisik nyeri, demam dan bengkak banyak diungkapkan oleh para ahli dan peneliti, diantaranya yang diungkapkan oleh Widoyono (2008) bahwa gejala timbul akibat manifestasi kronik penyakit. Pada fase akut bersifat tidak khas, yaitu demam berulang-ulang, kemudian gejala lebih sering apabila partisipan bekerja terlalu berat, dapat timbul benjolan dan terasa nyeri pada lipat paha atau ketiak dengan tidak ada luka di badan. Selanjutnya menurut Marty (2011) lymphedema biasanya terjadi setelah serangan akut berulang kali.

Keterbatasan aktivitas dapat diakibatkan karena adanya perasaan nyeri yang tidak dapat ditolelir dan karena ektremitas yang membesar sehingga menimbulkan perasan berat, susah menggerakkan anggota tubuh yang akan mengurangi kemampuan untuk melakukan aktivitas. Hasil penelitian diatas didukung oleh penelitian Wijesinghe, dkk. 
Lilis Lismayanti: Pengalaman Hidup Orang Terinfeksi Filariasis

(2007) bahwa mayoritas (95\%) pasien filariasis mengalami dampak pada tungkai dan ada hubungan yang signifikan dengan kesulitan dalam berjalan $(\mathrm{p}-=0,023)$. Pada anggota badan yang bengkak memengaruhi kerja $(52 \%)$. Hasil penelitian inipun sejalan dengan penelitian Kumari, dkk. (2005) dalam keadaan akut, yang paling parah terkena dampak adalah mobilitas, penderita tidak dapat berjalan atau bergerak dan hanya terbatas di tempat tidur. Penderita sangat tergantung pada keluarga untuk perawatan dirinya, begitu pula hasil penelitian yang dilakukan oleh Omudu, dkk. (2011) dan Kanda (2004) bahwa pada episode akut membatasi kemampuan perempuan untuk melakukan pekerjaan rumah tangga seperti memasak, membersihkan rumah, mencuci dan membawa anak-anak.

Serangan berulang pada partisipan terjadi karena kecapean atau setelah bekerja berat. Terjadi karena dengan kecapean atau kerja berat dapat meningkatkan respons imun, yang dapat meningkatkan pelepasan mediator inflamasi sehingga gejala nyeri dan demam sering terjadi berulang kali. Faktor pencetus kambuhnya gejala filariasis sesuai dengan yang dikemukakan oleh Widoyono (2008) dan Oemiyati (1990) bahwa gejala lebih sering bila penderita bekerja terlalu berat. Selain itu, hasil penelitian dengan pendekatan studi kasus yang dilakukan Kumari, dkk. (2005), ditemukan partisipan yang takut untuk bepergian kemanapun tanpa ditemani karena takut dengan serangan-serangan yang terjadi secara mendadak setelah kecapaian.

Hasil penelitian tentang pengalaman penderita filariasis terkait aspek emosi dan psikologis didapatkan tiga subtema yaitu malu, jengkel, pasrah.

Gangguan fisik dan penderita filariasis mempunyai dampak yang sangat besar terhadap psikologis penderita yang dapat mengganggu pembentukan konsep dirinya. Manifestasi klinis filariasis seperti pembesaran kaki akan menimbulkan perasaan malu, beratnya kecacatan akan sangat memengaruhi beban psikologis penderita. Adanya stigma menjijikkan akan meningkatkan perasaan malu pada partisipan, yang sangat berhubungan dengan tingkat kecacatan, seperti yang dikemukakan oleh Alonso dan Alvar (2010) dan Wynd, dkk. (2001) bahwa tingkat stigmatisasi pada limpatik filariasis tampaknya akan secara langsung berhubungan dengan adanya keparahan yang terlihat pada penyakitnya. Perasaan malu juga dikemukakan oleh Urrahman (2011) dan Kanda (2004), manifestasi klinis filariasis akut seperti pembesaran kaki, lengan, payudara serta alat kelamin dapat memberikan gambaran yang menakutkan. Manifestasi klinis tersebut akan menimbulkan perasaan malu, rendah diri, depresi, menyendiri, dan menolak diri. Pada studi kualitatif yang dilakukan oleh Perera, Whitehead, Molyneux, Weerarooriya, dan Gunatilleke (2007) bahwa orang dengan limpatik filariasis mengalami tanggapan negatif dari orang lain terhadap anggota tubuh yang cacat.

Gejala klinis yang irreversible membuat penderita menjadi jengkel. Perasaan jengkel merupakan manifestasi dari keputusasaan, penolakan dan ungkapan perasaan marah. Kanda (2004) mengemukakan bahwa penyakit dengan jangka waktu yang singkat dan tidak mengancam kehidupannya akan menimbulkan sedikit perubahan perilaku, sedangkan penyakit berat yang mengancam kehidupannya dapat menimbulkan perubahan emosi dan perilaku yang lebih luas seperti cemas, shock, penolakan, marah, dan menarik diri.

Menghadapi penyakit yang tidak kunjung sembuh pada akhirnya partisipan merasa pasrah menerima kenyataan penyakitnya. Pasrah memiliki makna berserah diri kepada Allah tanpa ada upaya lagi untuk melakukan pengobatan, hal ini juga memiliki makna bahwa partisipan telah bosan dan putus asa dengan upaya yang telah dilakukan. Menurut World Health Organization (WHO) dalam (Kanda, 2004) terkait dengan aspek sosial, beban psikologis juga memengaruhi kehidupan pasien, biasanya orang depresi, sikap pasif, putus asa, dan tidak percaya diri, dalam beberapa kasus bahkan mengarah ke bunuh diri.

Hasil penelitian tentang pengalaman orang terinfeksi Filariasis selama menjalani beban sosial ekonomi didapatkan dua subtema yaitu menarik diri dari interaksi sosial dan kesulitan ekonomi.

a. Menarik diri dari interaksi sosial Munculnya manifestasi klinis bengkak akan 
Lilis Lismayanti: Pengalaman Hidup Orang Terinfeksi Filariasis

menimbulkan perasaan malu pada partisipan. Semakin parah tingkat kecacatan, maka akan meningkat pula stigmatisasi sosial bahwa penyakit filariasis adalah penyakit yang menakutkan dan menjijikan. Perasaan malu dan stigma yang ada di masyarakat, menyebabkan muncul upaya partisipan untuk menyembunyikan kecacatannya, salah satunya dengan menarik diri dari interaksi sosial. Sejalan dengan yang dikemukakan oleh Urrahman (2011) dan Kanda (2004) bahwa manifestasi klinis filariasis akut seperti pembesaran kaki, lengan, payudara serta alat kelamin dapat memberikan gambaran yang menakutkan. Manifestasi klinis tersebut akan menimbulkan perasaan malu, rendah diri, depresi, menyendiri, menolak diri. Penyakit dengan jangka waktu yang singkat dan tidak mengancam kehidupannya akan menimbulkan sedikit perubahan perilaku, sedangkan penyakit berat, yang mengancam kehidupannya dapat menimbulkan perubahan emosi dan perilaku yang lebih luas seperti ansietas, shock, penolakan, marah, dan menarik diri.

\section{b. Kesulitan ekonomi}

Upaya menarik diri partisipan akan kehilangan kesempatan untuk bekerja, sehingga akan menurunkan pendapatannya dan akhirnya terjadi kesulitan ekonomi. Kesulitan ekonomi ini bukan hanya merupakan dampak dari menarik diri dari interaksi sosial, tetetapi juga karena adanya stigma sehingga partisipan akan sulit untuk mencari pekerjaan bahkan ada juga partisipan yang dikeluarkan dari pekerjaannya. Selain itu dapat menurunkan produktifitas karena keterbatasan kemampuan untuk melakukan aktivitas yang akan berdampak terhadap kondisi ekonominya. Kondisi ekonomi ini diperparah dengan kebutuhan partisipan untuk biaya pengobatan, sehingga kondisi ekonomi ini semakin sulit.

Hasil penelitian di atas sesuai dengan hasil penelitian yang dilakukan Kumari, dkk. (2005) dalam studi kasusnya bahwa dalam keadaan akut yang paling parah terkena dampak adalah mobilitas, penderita tidak dapat berjalan atau bergerak dan hanya terbatas di tempat tidur. Penderita sangat tergantung pada keluarga untuk perawatan dirinya. Penderita setiap episode akut kehilangan pekerjaan dan pendapatan, dan harus memenuhi pengeluaran untuk pengobatan. Hasil penelitian Coreil, Mayard, Louis, dan Adis (1998) dicatat bahwa selama sakit akan menurunkan mobilitas, sehingga mereka tidak mempunyai kemampuan untuk menjual hasil kebunnya ke pasar, sehingga akan menurunkan penghasilannya, sedangkan menurut Gyapong, Gyapong, Weis, dan Tanner (2000) dan Suma, Shenoy, dan Kumaraswami (2003) ketika penyakit berkembang maka individu yang terkena filariasis dan mengalami kecacatan semakin menurunkan kontribusi mereka terhadap tenaga kerja, sehingga akan menjadi beban ekonomi rumah tangga yang lebih lanjut.

Hasil Penelitian yang berkenaan dengan pengalaman penderita filariasis dalam mengakses pelayanan kesehatan didapatkan tiga subtema, yaitu bosan dengan penyakit yang tidak kunjung sembuh setelah beberapa kali ke pelayanan kesehatan akhirnya mencari alternatif pengobatan tradisional dan dukun, pelayanan yang kurang memuaskan, dan harapan pelayanan yang lebih baik.

Pola pencarian pengobatan sangat dipengaruhi oleh norma dan budaya yang melekat pada individu dan keluarga, selain itu juga dipengaruhi oleh pemahaman yang kurang dari partisipan tentang pengobatan filariasis. Asumsi yang melekat pada partisipan bahwa pengobatan yang baik adalah apabila setelah habis makan obat langsung sembuh, sehingga ketika setelah berobat tidak merasakan perubahan, maka partisipan dan atau keluarga memutuskan untuk mencari pengobatan yang lainnya baik ke pelayanan kesehatan lagi maupun untuk pengobatan alternatif lainnya.

Persepsi yang salah tentang pengobatan filariasis, mungkin dikarenakan hanya dua dari tujuh partisipan yang telah mendapatkan kunjungan dari tenaga kesehatan, itupun mereka belum mendapatkan informasi yang lengkap tentang filariasis, baik tentang penyakitnya, pengobatan maupun perawatannya, padahal orang yang terinfeksi filariasis sangat memerlukan perawatan yang berkelanjutan, agar dapat menghadapi hidupnya secara optimal. Selain itu, filariasis merupakan penyakit yang berbasis lingkungan, artinya masyarakat yang berada disekitarnya mempunyai risiko terjadi fila- 
Lilis Lismayanti: Pengalaman Hidup Orang Terinfeksi Filariasis

riasis, sehingga tugas tenaga kesehatan bukan hanya berfokus pada yang sakit, tetetapi juga bagi yang berisiko dan juga yang sehat.

Fenomena diatas dikemukakan oleh Kanda (2004), bahwa perawatan lymphedema memerlukan upaya intensif berkelanjutan, sangat penting untuk memahami latar belakang dan persepsi penyakit sebelum memperkenalkan pencegahan dan rejimen pengobatan. Hasil penelitiannya menunjukan bahwa partisipan banyak yang lebih suka mengunjungi dukun dan menggunakan obat herbal. Pengetahuan partisipan tentang penyakit ini lebih berkaitan dengan dimensi budaya dan spiritual tradisional.

Kurangnya informasi yang diberikan di pelayanan kesehatan membuat partisipan menjadi kurang puas dengan pelayanan kesehatan, karena pemahaman partisipan yang kurang tentang filariasis mulai dari konsep penyakit sampai dengan bagaimana cara pengobatan dan penatalaksanaan di rumah, sehingga partisipan tidak melakukan pengobatan yang tidak teratur. Di samping kurangnya informasi, kurang puasnya partisipan terhadap pelayanan kesehatan karena ada kecenderungan perbedaan pelayanan yang diberikan dikarenakan melihat fisik yang begitu berbeda dengan yang lainnya. Pada penelitian ini partisipan mengungkapkan bahwa pelayanan dari pihak rumah sakit ataupun puskesmas kurang memuaskan mungkin karena tidak mampu dan keadaannya seperti ini (cacat). Naeem (2011) mengemukakan dalam artikelnya bahwa peningkatan kualitas pelayanan dari petugas kesehatan merupakan salah satu cara yang sangat penting dalam upaya pemberantasan dan penanganan penyakit filariasis.

Penanganan filariasis memang merupakan tantangan bagi seluruh tenaga kesehatan di Indonesia. Pencegahan filariasis sangat penting untuk mencegah terjadinya kecacatan akibat filariasis. Disisi lain, penanganan rehabilitatif juga tidak kalah pentingnya, terutama untuk meminimalkan kecacatan yang telah diderita akibat filariasis dan membatu adaptasi penderita filariasis dalam kehidupan seharihari.

Ketidakpuasan dalam mendapatkan pelayanan kesehatan akan melahirkan harapan dalam mengakses pelayanan yang lebih baik. Harapan partisipan untuk mendapatkan pelayanan kesehatan yang lebih baik menunjukkan bahwa pelayanan yang baik, yang sesuai dengan harapan partisipan selama ini belum terwujudkan. Temuan ini sejalan dengan penelitian yang dilakukan oleh Person, dkk. (2006) bahwa partisipan ingin mengetahui dan dapat melakukan bagaimana cara merawatnya dan kemana harus mencari pelayanan kesehatan.

\section{Simpulan}

Berdasarkan hasil penelitian diatas dapat disimpulkan bahwa pengalaman hidup orang terinfeksi filariasis di Kota Tasikmalaya, berkaitan lima tema yaitu emosi, persepsi, gejala klinis, ekonomi dan sosial serta pengalam dalam mengakses pelayanan kesehatan. Hasil penelitian ini dapat dijadikan acuan untuk meningkatkan pelayanan keperawatan komunitas, baik secara fisik, psikologis, sosial dan ekonomi. Implikasi dari penelitian ini diperlukan pengobatan yang efektif untuk mengurangi keluhan fisik. Pencegahan filariasis juga merupakan hal yang sangat penting untuk mengurangi risiko penularan, selain itu, proses rehabilitatif juga penting untuk mengurangi kecacatan dan membantu adaptasi penderita dalam kehidupannya secara biologis, psikologis, sosial dan spiritual.

\section{Daftar Pustaka}

Alonso, L. M. \& Alvar, J. (2010). Stigmatizing neglected tropical disease: A systematic review. Social Medicine, 5 (4). Diakses dari http:www.socialmedicine.info.

Bose, K. (2011). Control of lymphatic Filariasis through patient empowerment. Wounds International. Diakses dari http:// www.woundsinternational.com.

Coreil, J., Mayard, G., Louis, C. J., \& Addis, D. (1998). Filarial elephantiasis among Haitian women: Social context and behavioral factors in treatment. Trop Med Int Health, 3(6), 467-473. Diakses dari www. 
Lilis Lismayanti: Pengalaman Hidup Orang Terinfeksi Filariasis

ncbi.nlm.nih.gov/pubmed/9657509.

Dinas Kesehatan Provinsi Jawa Barat. (2005). Kartu pengobatan keluarga dan monitoring efek samping pengobatan Filariasis. Bandung: P2 Filariasis .

Gyapong, M., Gyapong, J., Weiss, M., \& Tanner, M. (2000). The burden of hydrocele on men in Northern Ghana. Acta Trop, 77(3), 287-294. Diakses dari www.ncbi.nlm.nih. gov/pubmed.

Hotez, P. J., Molyneux, D. H., Fenwick, A., Kumaresan, J., Sachs, S. E., \& Sachs, J.D.(2007). Control of neglected tropical diseases. The New England Journal of Medicine, 10 (27), 1018-1027.

Kanda, K. (2004). The quality of life among lymphedema patients due to lymphatic filariasis in three rural towns in Haiti Florida. (Unpublished M.Sc. Thesis Univerversity of Shouth Florida ). Diakses dari http://etd.fcla. edu/SF/SFE0000407/Kanda_thesis_final.pdf

Kementrian Kesehatan Republik Indonesia. (2010). Profil kesehatan Indonesia tahun 2009. Jakarta: Kementrian Kesehatan Republik Indonesia. ISBN 978-602-8937$18-4$

Kementrian Kesehatan Republik Indonesia. (2005). Pedoman pemberantasan filariasis : Lampiran II keputusan menteri kesehatan Nomor:1582/Menkes/SK/XI/2005. Diakses dari http://www.hukor.depkes.go.id

Krentel, A., Fischer, P., Manoempil, P., Supali, T., Servais, G., \& Ruckert, P. (2006). Using knowledge, attitudes and practice (KAP) surveys on lymphatic Filariasis to prepare a health promotion campaign for mass drug administration in Alor District, Indonesia. Tropical Medicine and International Health. 2(2), 1731-1740. doi: 10.1111/j.13653156.2006.01720.x

Kumari, A. K., Harichandrakumar, K. T., Das, L. K., \& Krishnamoorthy, K. (2005). Physical and psychosocial burden due to lymphatic Filariasis as perceived by patient and medical experts. Tropical Medicine and International Health, 10(6), 567-573. Diakses dari www. ncbi.nlm.nih.gov/pubmed/15941420.

Marty, A. M. (2011). Dermatologic manifestations of filariasis. Diakses dari http://emedicine.medscape.com/article

Naeem,Z. (2011). Fighting stigma: Lymphatic filariasis. The Journal Global Health, 881. Diakses dari: www.ghjjournal.org.

Omudu,Agbo,E.,Okafor, \& Chukwuemenam, F. (2011). Gender dimensions of knowledge, physical and psycho-social burden due to lymphatic filariasis in Benue State, Nogeria. Journal of Parasitology and Vector Biolog, $3(2), \quad 22-28$. Diakses dari http://www. academicjournals.org/JPVB. ISSN 21412510 .

Perera, M., Whitehead, M., Molyneux, D., Weerarooriya, M., \& Gunatilleke, G. (2007). Neglected patients with a neglected diseses? A qualitative study of lymphatic Filariasis. Flos Negtected Tropical Disease, 1(2) . e128. doi:10.1371/journal.pntd.0000128.

Person, B., Addiss, D.G., Bartholomew, L.K., Meijer, C., Pou, V., \& Borne, B. (2006). Health-seeking behaviors and selfcare practices of dominican women with lymphoedema og The Leg: Implications for lymphoedema management programs. Filaria Journal, 5(13). doi:10.1186/14752883-5-13.

Sudomo, M. (2008). Penyakit parasitik yang kurang diperhatikan di Indonesia Orasi pengukuhan profesor riset bidang entomologi dan moluska. Badan Penelitian dan Pengembangan Kesehatan Departemen Kesehatan Republik Indonesia. Diakses dari http://www.litbang.depkes.go.id.

Suma, T.K., Shenoy, R.K., Kumaraswami, V. (2003). A qualitative study of the perceptions. practices and socio-psychological suffering related to chronic brugian filariasis in Kerala, Southern India. Ann Trop Med Parasitol, 97(8). 839-845. Diakses dari: www.ncbi. nlm.nih.gov/pubmed. 
Lilis Lismayanti: Pengalaman Hidup Orang Terinfeksi Filariasis

Urrahman, Z. (2011). Gambaran konsep diri penderita filariasis limfatik (elephantiasis) $d i$ Kota Tangerang Selatan. Skripsi yang tidak dipublikasikan, Universitas Islam Negeri Jakarta.

WHO, (2011). Programme vector borne diseases control. Jakarta: World Health Organization.

Widoyono, (2008). Penyakit tropis: Epidemiologi, penularan, pencegahan \& pemberantasannya. Jakarta: Erlangga.

Wijesinghe, RS., Wickremasinghe, A. W., Ekanayake, S., \& Perera, M.S.A. (2007). Physical disability and psychosocial impact due to chronic filarial lymphoedema in Sri
Lanka . Filaria Journal , 8. doi:10.1186/14752883-6-4.

Wynd, S., Melrose, W.D., Durrheim,D. N., Carron, J., Gyapong,M. (2007). Understanding the community impact of lymphatic filariasis: Review of the sociocultural literature. Bulletin of the World Health Organization ,85(6). 493-498. doi; 10.2471/BLT.06.031047.

Wynd, S., Carron, J., Selve, B., Leggat, P.A., Melrose, W., \& Durrheim, D.N. (2007). Qualitative analysis of the impact of a lymphatic filariasis elimination programme using mass drug administration on Miasma. Filaria Journal, 6(1). doi:10.1186/14752883-6-1. 